\title{
Preliminary studies on steel slag as a substitute for coarse aggregate on concrete
}

\author{
Rahmi Karolina*, and Jannes Pandiangan \\ Department of Civil Engineering,University of Sumatera Utara, Medan, Indonesia
}

\begin{abstract}
The development of science and technology in the field of construction that is rapidly increasing, is always followed by the growing community needs for infrastructure facilities, such as buildings, bridges and other construction. One of the key element in that development is concrete. Due to the rapid development of science and technology in the field of construction, it's required a building material which has better advantage than the materials of the existing building. To obtain a better building materials, one alternative is the use of waste as aggregate in concrete mixture. In this study the authors using waste steel waste (steel slag) as a substitute for coarse aggregate. Steel slag used is steel waste from PT. Growth Sumatra Industry. The gravel substitution variations is $0 \%, 15 \%$, and $25 \%$ and the testing was done by the slump test, compressive strength and flexural strength of concrete. From the test results obtained optimum compressive strength variation occurs in $25 \%$ substitution of steel slag gravel amounted to $40.481 \mathrm{MPa}$, whereas for the optimum bending capacity contained in variations of $25 \%$ substitution of steel slag gravel amounted to $19.592 \mathrm{~N} / \mathrm{mm}^{2}$. And for optimum slump value obtained on the variation of normal concrete. This shows the workability of the concrete normally higher than the other variation. Keywords: Steel slag, compressive strength, flexural strength
\end{abstract}

\section{Introduction}

Knowledge and technology in construction are developing rapidly and followed by the increase in people's need for facility and infrastructure such as building construction, bridge, and the other constructions. The building itself consists of various components, and one of the main components in construction is concrete.

Concrete is a construction material which consists of fine aggregate, coarse aggregate, cement, and water. There are some factors which have to be heeded in making concrete mixture; they are material, proportion of the mixture, and executing. From these three factors, material is the natural resource which will gradually be used up and cannot be renewed. Therefore, an alternative should found to substitute it and steel slag is considered appropriate to replace it. Slag is the residue of high furnace combustion as the result of steel

\footnotetext{
${ }^{*}$ Corresponding author: rachmie caroline@yahoo.co.id
} 
smelting which produces steel slag which physically resembles. Using steel slag as coarse aggregate will help conserve environment.

In many countries, slag is commonly used as the substitute for aggregate, either as the mixture of concrete or as the material for foundation hardening. In using it, slag is usually considered as aggregate; therefore, physical requirement of aggregate is considered as the same as the physical requirement for aggregate. Since chemical characteristic of slag is far different from the chemical characteristic of natural aggregate, some other components are needed in order that slag can be used as the substitute for standard aggregate; the requirement is preservation BSI, 2007). Some advantages of using steel slag in concrete mixture as follows:

- Heightening the compressive strength of concrete since the increase in compressive strength tends to slow down;

- Increasing the ratio between flexibility and concrete compressive strength;

- Reducing the variation of concrete compressive strength;

- Heightening resistance against sulfate in the sea water;

- Reducing the attack of alkaline silica;

- Reducing hydrated heat and decreasing temperature;

- Heightening preservation due to the influence of volume change;

- Reducing porosity and chloride attack

\section{Literature review}

\subsection{Steel slag}

According to Paul Nugraha and Antoni (2007), slag is the residue material from pig iron in which its process uses furnace which fuel comes from blast. Smelting steel begins with eliminating steel polluting ions, such as aluminum, silicon, and phosphor. In order to eliminate the polluting ions, it is necessary to have calcium which is found on the limestone. The mixture of calcium, aluminum, silicon, sand phosphor will shape slag which reacts in the temperature of $1,600^{\circ} \mathrm{C}$ and form liquid. When this liquid is cooled, crystal will be formed to resemble the form of aggregate. Slag has particle pored granules on its surface and good gradation with different variation in particle shapes.

Slag is defined in ASTM C.989 as "...standard specification for ground granulated blast Furnace Slag for use in concrete and mortar" *ASTMJ, 1995: 494). Slag is a non-metal product, a fine-formed material and the granular of the result of combustion which is cooled by, for example, immersing it into the water.

Some factors for determining cementitious quality in slag are as follows: chemical composition, alkaline concentration and reaction against system, glass content in slag, fineness, and temperature which is caused during the process of hydration.

Steel slag is hard, solid material which contains an amount of free iron so that it gives high density and hardness. The use of steel slag as an concrete aggregate with Portland cement can cause high quality of concrete. Steel slag aggregate has uneven surface texture and has prismatic shape. It also has high volume weight and specific gravity, high friction coefficient, and its water absorption is moderate (until 3\%). Steel lag has good character for using aggregate, good abrasion endurance, good characteristics of its strength, and high supporting power. 


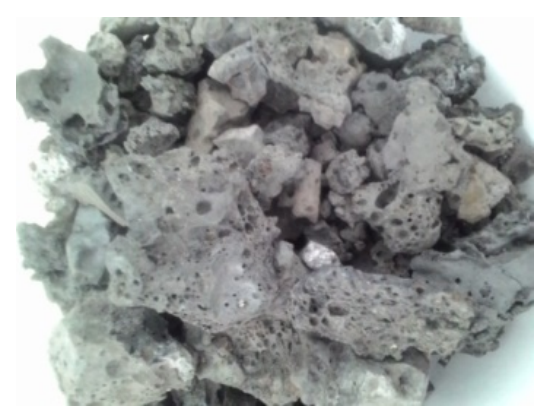

Fig. 1.Steel slag from PT. Growth Sumatra

Chemical element content in steel slag can be seen in Table 1 below,

Table 1. Chemical element content in steel slag.

\begin{tabular}{|c|c|c|c|c|}
\hline No. & Parameter & Unit & Result & Method \\
\hline 1 & Lead $(\mathrm{Pb})$ & $\mathrm{Mg} / \mathrm{kg}$ & 26,6 & AAS \\
\hline 2 & Cadmium $(\mathrm{Cd})$ & $\mathrm{Mg} / \mathrm{kg}$ & $<0,003$ & AAS \\
\hline 3 & Copper $(\mathrm{Cu})$ & $\mathrm{Mg} / \mathrm{kg}$ & 97,5 & AAS \\
\hline 4 & Chromium $(\mathrm{Cr})$ & $\mathrm{Mg} / \mathrm{kg}$ & 5353 & AAS \\
\hline 5 & Silver $(\mathrm{Ag})$ & $\mathrm{Mg} / \mathrm{kg}$ & $<0,001$ & AAS \\
\hline 6 & Selenium $(\mathrm{Se})$ & $\mathrm{Mg} / \mathrm{kg}$ & $<0,01$ & AAS \\
\hline 7 & Barium $(\mathrm{Ba})$ & $\mathrm{Mg} / \mathrm{kg}$ & 817 & AAS \\
\hline 8 & Mercury $(\mathrm{Hg})$ & $\mathrm{Mg} / \mathrm{kg}$ & 0,38 & AAS \\
\hline 9 & Arsenic $(\mathrm{As})$ & $\mathrm{Mg} / \mathrm{kg}$ & 0,21 & AAS \\
\hline
\end{tabular}

Source: Laboratory of IndustryResearch and Standardization Center Medan 2016

\section{Research method}

\subsection{Flowchart}

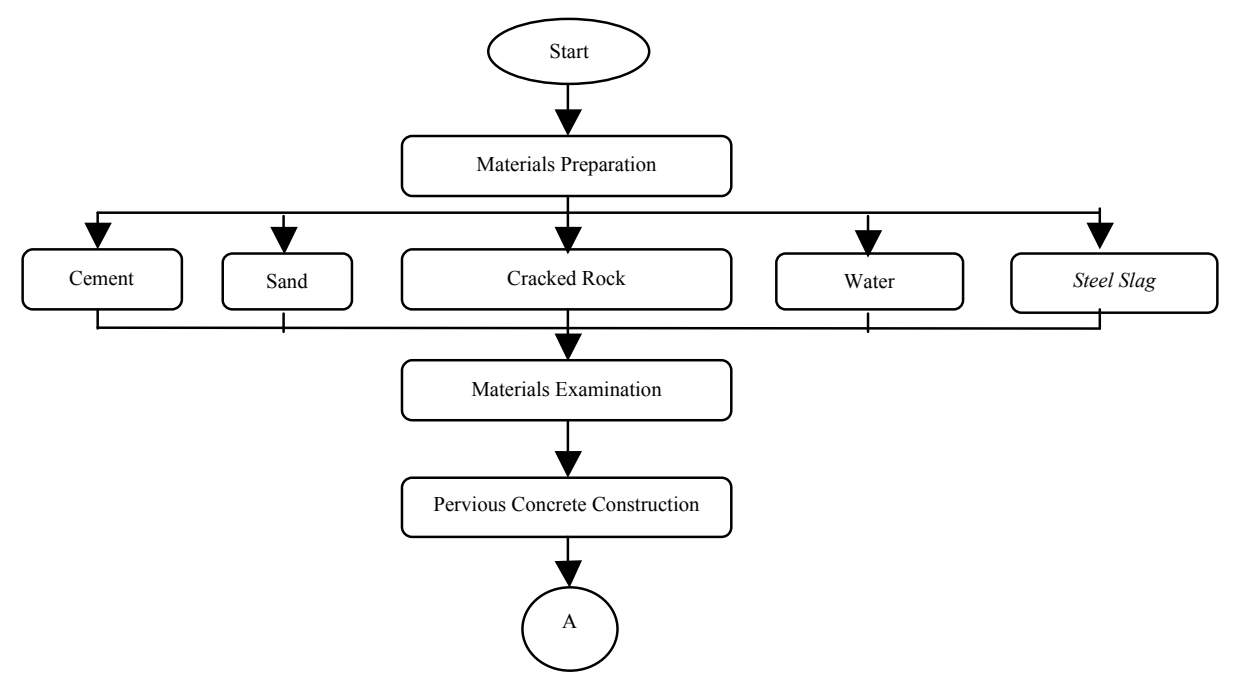




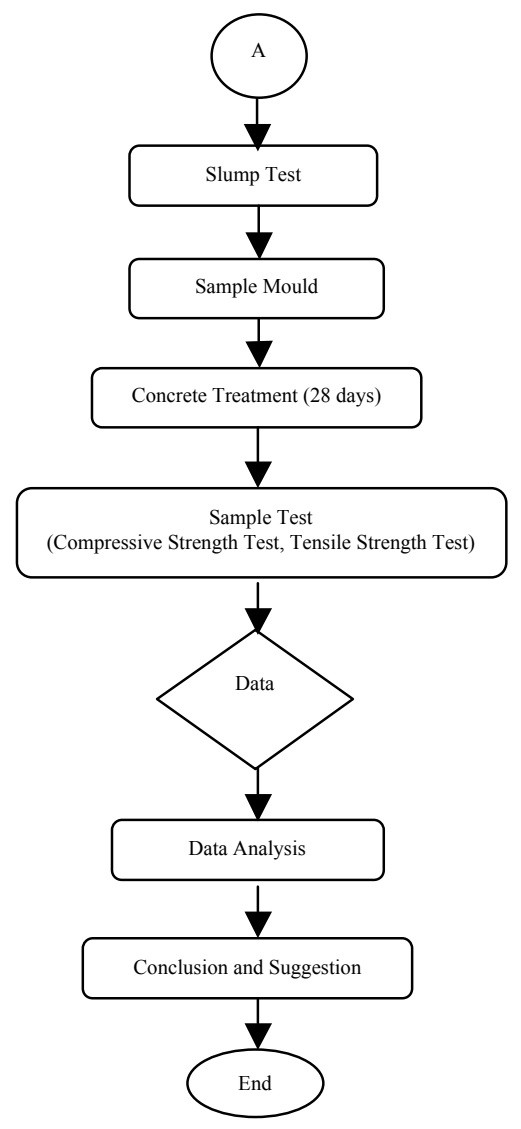

Fig. 2. Research's flowchart

\section{Results and discussion}

\subsection{Slump test}

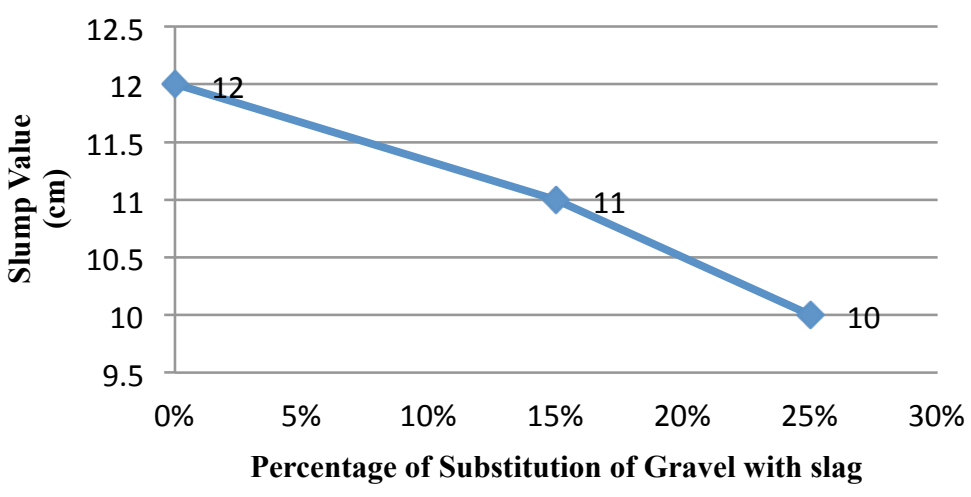

Fig.3.Slump value graph in the percentage of substitution of gravels with steel slag. 


\subsection{Compressive strength of concrete cylinder}

This testing was aimed to find out the value of concrete compressive strength by using various variations of substitution of coarse aggregate with steel slag, compared with normal concrete in which specimens in the form of cylinder which construction and maintenance were carried out in Concrete Laboratory. The testing was done when the concrete was 28 days old, based on SNI 03-6429-2000, using the method of Concrete Compressive Strength Testing.

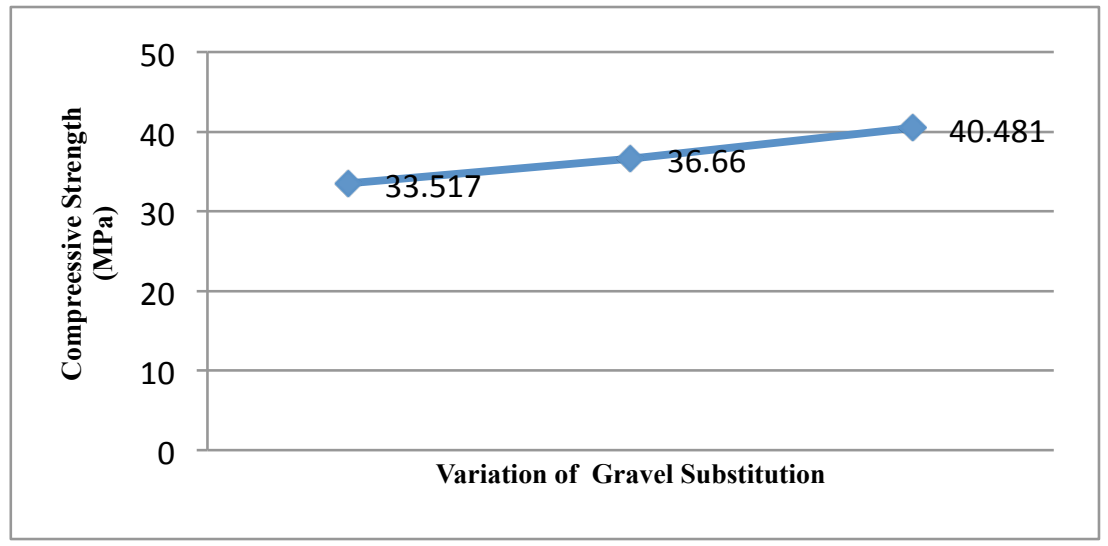

Fig.4. Graph of the result of concrete compressive strength testing

From Figure 4, it was found that there was the increase in the use of steel slag straight proportional to the increase in concrete compressive strength. Therefore, it could be concluded that the increase in the use of steel slag as coarse aggregate could increase concrete compressive strength.

\subsection{Reinforced concrete deflection testing}

Reinforced concrete deflection testing was done by using Hydraulic Jack and 3 (three) Dial Indicator with the rage of $75 \mathrm{~cm}$ respectively,

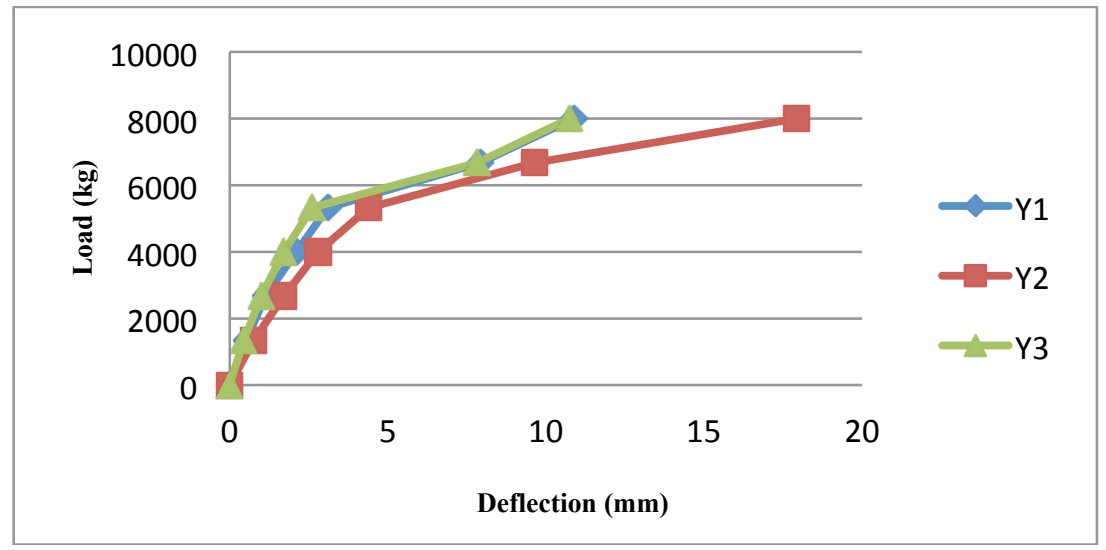

Fig. 5. Graph of correlation of load with reinforced concrete beam deflection (Normal) 


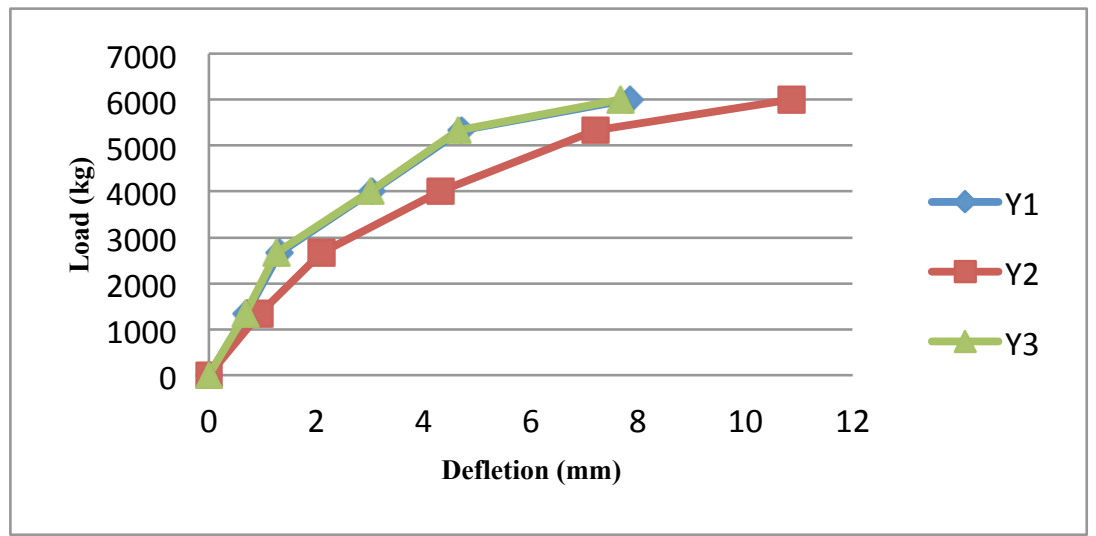

Fig. 6. Graph of correlation of load reinforced concrete beam deflection (substitution of $15 \%$ of gravels with slag)

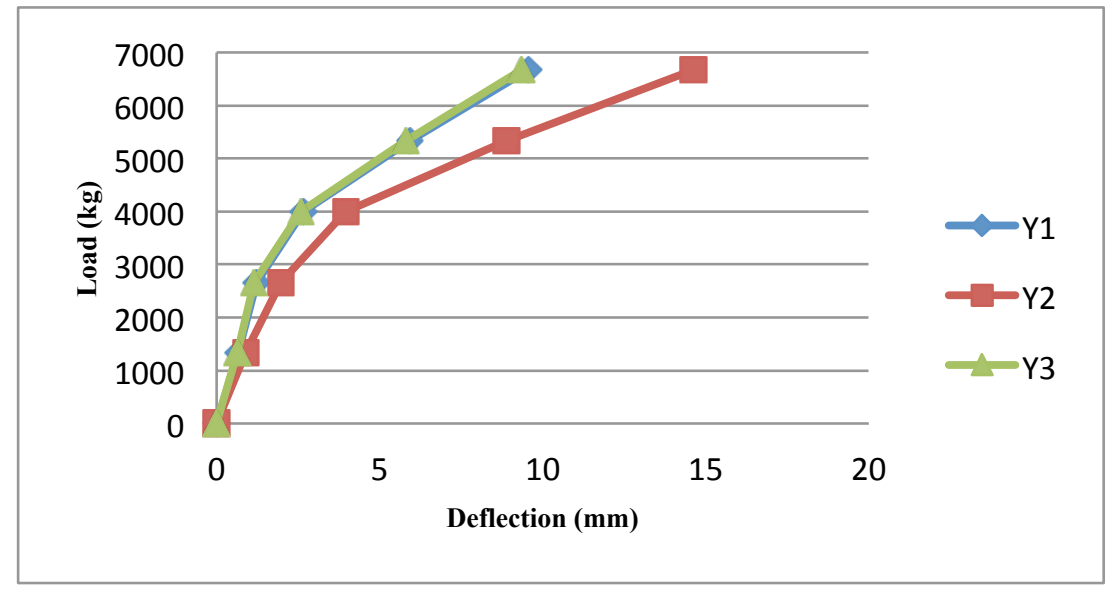

Fig.7. Graph of Correlation of load with reinforced concrete beam deflection (substitution of $25 \%$ gravels with slag)

From Figure 5, 6, and 7, it was found that the more substitution of gravels with steel slag was the bigger the load carried by the beam, and the more the deflection occurred. It was the same as the concrete compressive strength, the increase in using steel slag as coarse aggregate could increasere in forced concrete beam deflection.

\subsubsection{Pliancy capacity of reinforced concrete}

The data of the calculation of pliancy capacity, based on tension for reinforced concrete beam could be seen in Table 2 below, 
Table 2. Pliancy capacity of reinforced concrete beam (normal)

\begin{tabular}{|c|c|c|c|c|c|c|c|c|}
\hline $\begin{array}{c}\text { Load } \\
\mathrm{P} \\
(\mathrm{Kg})\end{array}$ & $\begin{array}{c}\mathbf{\varepsilon c} \\
\left(\times 10^{-4}\right)\end{array}$ & $\begin{array}{c}\mathbf{\varepsilon s} \\
\left({ }^{\times} 10^{-4}\right)\end{array}$ & $\begin{array}{c}\mathbf{F c} \\
\left(\mathrm{N} / \mathrm{mm}^{2}\right)\end{array}$ & $\begin{array}{c}\mathbf{F s} \\
\left(\mathrm{N} / \mathrm{mm}^{2}\right)\end{array}$ & $\begin{array}{c}\mathbf{M n} \\
(\mathrm{Nmm}) \\
\left(\times 10^{6}\right)\end{array}$ & $\begin{array}{c}\mathbf{P n} \\
(\mathrm{Kg}) \\
\left(\times 10^{2}\right)\end{array}$ & $\begin{array}{c}\boldsymbol{\sigma} \\
\left(\mathrm{N} / \mathrm{mm}^{2}\right)\end{array}$ & $\mathbf{P} / \mathbf{P n}$ \\
\hline 0 & 0.00 & 0.00 & 0.00 & 0.00 & 0.00 & 0.00 & 0.00 & 0.000 \\
\hline 1,333 & 1.54 & 4.21 & 4.20 & 84.14 & 6.39 & 12.79 & 0.88 & 1.042 \\
\hline 2,666 & 3.41 & 9.30 & 9.29 & 185.99 & 14.13 & 28.27 & 1.96 & 0.943 \\
\hline 3,999 & 7.02 & 19.13 & 19.11 & 382.60 & 29.07 & 58.15 & 4.03 & 0.688 \\
\hline 5,332 & 11.72 & 31.93 & 31.89 & 638.56 & 48.52 & 97.04 & 6.73 & 0.549 \\
\hline $5,998$. & 17.66 & 48.09 & 48.04 & 961.82 & 73.09 & 146.1 & 10.13 & 0.410 \\
\hline \multicolumn{70}{|c|}{ Mean Coefficient } \\
\hline
\end{tabular}

Table 3. Pliancy capacity of reinforced (substitution of $15 \%$ of gravels with slag)

\begin{tabular}{|c|c|c|c|c|c|c|c|c|}
\hline $\begin{array}{c}\text { Load } \\
\mathrm{P} \\
(\mathrm{Kg})\end{array}$ & $\begin{array}{c}\mathbf{\varepsilon c} \\
\left(\times 10^{-4}\right)\end{array}$ & $\begin{array}{c}\mathbf{\varepsilon s} \\
\left(\times 10^{-4}\right)\end{array}$ & $\begin{array}{c}\mathbf{f c} \\
\left(\mathrm{N} / \mathrm{mm}^{2}\right)\end{array}$ & $\begin{array}{c}\mathbf{f s} \\
\left(\mathrm{N} / \mathrm{mm}^{2}\right)\end{array}$ & $\begin{array}{c}\mathbf{M n} \\
(\mathrm{Nmm}) \\
\left(\times 10^{6}\right)\end{array}$ & $\begin{array}{c}\mathbf{P n} \\
(\mathrm{Kg}) \\
\left(\times 10^{2}\right)\end{array}$ & $\begin{array}{c}\boldsymbol{\sigma} \\
\left(\mathrm{N} / \mathrm{mm}^{2}\right)\end{array}$ & $\mathbf{P} / \mathbf{P n}$ \\
\hline 0 & 0.00 & 0.00 & 0.00 & 0.00 & 0.00 & 0.00 & 0.00 & 0.000 \\
\hline 1,333 & 1.43 & 3.90 & 4.07 & 77.94 & 5.94 & 11.88 & 0.82 & 1.122 \\
\hline 2,666 & 3.20 & 8.72 & 9.11 & 174.47 & 13.30 & 26.60 & 1.84 & 1.002 \\
\hline 3,999 & 6.45 & 17.58 & 18.37 & 351.61 & 26.80 & 53.61 & 3.71 & 0.746 \\
\hline 5,332 & 14.45 & 39.37 & 41.13 & 787.35 & 60.04 & 120.07 & 8.32 & 0.444 \\
\hline 6,665 & 23.78 & 64.79 & 67.68 & 1295.72 & 98.79 & 197.59 & 13.70 & 0.337 \\
\hline \multicolumn{70}{|c|}{ Mean Coefficient } \\
\hline
\end{tabular}

Table 4.Pliancy capacity of reinforced concrete beam (substitution of $25 \%$ of gravels with slag)

\begin{tabular}{|c|c|c|c|c|c|c|c|c|}
\hline $\begin{array}{c}\text { Load } \\
\mathbf{P}\end{array}$ & $\begin{array}{c}\mathbf{\varepsilon c} \\
(\mathrm{Kg})\end{array}$ & $\begin{array}{c}\mathbf{\varepsilon s} \\
\left({ }^{-4}\right)\end{array}$ & $\begin{array}{c}\mathbf{f c} \\
\left(\mathrm{N} / 0^{-4}\right)\end{array}$ & $\begin{array}{c}\mathbf{f s} \\
\left(\mathrm{N} / \mathrm{mm}^{2}\right)\end{array}$ & $\begin{array}{c}\mathbf{M n} \\
(\mathrm{Nmm}) \\
\left(\times 10^{6}\right)\end{array}$ & $\begin{array}{c}\mathbf{P n} \\
(\mathrm{Kg}) \\
\left(\times 10^{2}\right)\end{array}$ & $\begin{array}{c}\boldsymbol{\sigma} \\
\left(\mathrm{N} / \mathrm{mm}^{2}\right)\end{array}$ & $\mathbf{P} / \mathbf{P n}$ \\
\hline 0 & 0.00 & 0.00 & 0.00 & 0.00 & 0.00 & 0.00 & 0.00 & 0.00 \\
\hline 1,33 & 1.24 & 4.84 & 3.71 & 96.86 & 6.34 & 12.67 & 0.82 & 1.05 \\
\hline 2,66 & 2.81 & 10.98 & 8.41 & 219.54 & 14.36 & 28.72 & 1.86 & 0.92 \\
\hline 3,99 & 4.63 & 18.08 & 13.84 & 361.60 & 23.66 & 47.31 & 3.06 & 0.84 \\
\hline 5,33 & 7.28 & 28.41 & 21.76 & 568.22 & 37.17 & 74.35 & 4.80 & 0.71 \\
\hline 6,66 & 15.96 & 62.31 & 47.71 & 1246.2 & 81.53 & 163.06 & 10.55 & 0.40 \\
\hline 7,99 & 29.65 & 115.78 & 88.65 & 2315.5 & 151.48 & 302.97 & 19.59 & 0.26 \\
\hline \multicolumn{7}{|c|}{ Mean Coefficient } \\
\hline
\end{tabular}

From the Table 2, 3, and 4, it was found that the increase in the percentage of gravel substitution with steel slag would increase pliancy capacity of reinforced concrete. Therefore, it could be concluded that steel slag was good to be used in concrete mix. 


\section{Conclusion}

Based on the result of the research, it could be concluded that :

- Compressive strength of normal concrete $=33.517 \mathrm{MPa}$, compressive strength of concrete with substitution of $15 \%$ of gravels with slag $=36.66 \mathrm{MPa}$ (increased $10.18 \%$ from compressive strength of normal concrete, and compressive strength of substitution concrete of $25 \%$ of gravels with slag $=40.481 \mathrm{MPa}$ (increased $20.78 \%$ from compressive strength of normal concrete).

- Deflection in normal reinforced concrete beam at loading $\mathrm{P}=5998.5 \mathrm{~kg}$ was $10.86 \mathrm{~mm}$, for reinforced concrete beam with $15 \%$ of gravels with lag at loading $\mathrm{P}=6665 \mathrm{~kg}$ was $14.63 \mathrm{~mm}$, while for reinforced concrete beam with substitution of $25 \%$ gravels with lag at loading $\mathrm{P}=7998 \mathrm{~kg}$ was $17.93 \mathrm{~mm}$.

- Pliancy capacity in normal reinforced concrete beam was $10.138 \mathrm{~N} / \mathrm{mm}^{2}$, in substitution beam of $15 \%$ of gravels with lag was $13,704 \mathrm{~N} / \mathrm{mm}^{2}$, and in substitution beam of $25 \%$ of gravels with lag was $19,592 \mathrm{~N} / \mathrm{mm}^{2}$. Thus, usingsteel slag as coarse aggregate could increase pliancy in reinforced concrete.

\section{References}

1. R. Aryanti, Pengujian Lentur Balok Beton Bertulang dengan Menggunakan Modifikasi Alat Uji Tekan (Universitas Andalas, Padang, 2008), p. .

2. I. Dipohusodo, Struktur Beton Bertulang (PT.Gramedia Pustaka Utama, Jakarta, 1999)

3. T. Mulyono, Teknologi Beton (Penerbit ANDI, Yogyakarta, 2003), p. .

4. J. C. McCormac, Desain Beton Bertulang (PenertbitErlangga, Jakarta, 2004), p. .

5. E. G. Nawy, Beton Bertulang Suatu Pendekatan Dasar (Penerbit Refika Aditama, Bandung, 1998), p. .

6. P. Nugraha, Teknologi Beton (Penerbit ANDI, Yogyakarta, 2007), p. .

7. Y. Risdianto, Kajian Kuat Tekan Beton dengan Perbandingan Volume dan Perbandingan Beratuntuk Produksi Beton Massa Menggunakan Agregat Kasar Batu Pecah Merapi (Universitas Negeri Yogyakarta, Yogyakarta, 2013), p. .

8. D. Setiawan, Pengaruh Penggunaan Limbah Baja terhadap Kuat Karakteristik Beton (Universitas Kristen Maranatha, Bandung, 2014), p. .

9. Standar Nasional Indonesia. Tata Cara Perhitungan Struktur Beton untuk Bangunan Gedung. SNI $03-2847-2002$.

10. Standar Nasional Indonesia. Tata Cara Perhitungan Struktur Beton untuk Bangunan Gedung. SNI $03-2847-2013$.

11. S. Buen, Final project, Universitas Katolik Parahyangan, Bandung, 2013.

12. I. Wikana, Tinjauan Kuat Lentur Balok Beton Bertulang dengan Lapisan Mutu Beton yang Berbeda (UKRIM, Yogyakarta, 2007), p. . 